\title{
Distribution of CB1 Cannabinoid Receptors in the Amygdala and their Role in the Control of GABAergic Transmission
}

\author{
István Katona, ${ }^{1}$ Ede A. Rancz, ${ }^{1}$ László Acsády, ${ }^{1}$ Catherine Ledent, ${ }^{2}$ Ken Mackie, ${ }^{3}$ Norbert Hájos, ${ }^{1}$ and \\ Tamás F. Freund ${ }^{1}$ \\ 1/nstitute of Experimental Medicine, Hungarian Academy of Sciences, Budapest, H-1450, Hungary, ${ }^{2}$ Institut de Recherche \\ Interdisciplinaire en Biologie Humaine et Nucléaire, Université libre de Bruxelles, B-1070 Brussels, Belgium, and \\ ${ }^{3}$ Departments of Anesthesiology, and Physiology and Biophysics, University of Washington, Seattle, Washington 98195
}

Cannabinoids are the most popular illicit drugs used for recreational purposes worldwide. However, the neurobiological substrate of their mood-altering capacity has not been elucidated so far. Here we report that CB1 cannabinoid receptors are expressed at high levels in certain amygdala nuclei, especially in the lateral and basal nuclei, but are absent in other nuclei (e.g., in the central nucleus and in the medial nucleus). Expression of the CB1 protein was restricted to a distinct subpopulation of GABAergic interneurons corresponding to large cholecystokinin-positive cells. Detailed electron microscopic investigation revealed that $\mathrm{CB} 1$ receptors are located presynaptically on cholecystokinin-positive axon terminals, which establish symmetrical GABAergic synapses with their postsynaptic targets. The physiological consequence of this particular anatomical localization was investigated by whole-cell patchclamp recordings in principal cells of the lateral and basal nuclei. CB1 receptor agonists WIN 55,212-2 and CP 55,940 reduced the amplitude of $\mathrm{GABA}_{\mathrm{A}}$ receptor-mediated evoked and spontaneous IPSCs, whereas the action potentialindependent miniature IPSCs were not significantly affected. In contrast, CB1 receptor agonists were ineffective in changing the amplitude of IPSCs in the rat central nucleus and in the basal nucleus of CB1 knock-out mice. These results suggest that cannabinoids target specific elements in neuronal networks of given amygdala nuclei, where they presynaptically modulate GABAergic synaptic transmission. We propose that these anatomical and physiological features, characteristic of CB1 receptors in several forebrain regions, represent the neuronal substrate for endocannabinoids involved in retrograde synaptic signaling and may explain some of the emotionally relevant behavioral effects of cannabinoid exposure.

Key words: endocannabinoids; interneurons; inhibition; CCK; retrograde signaling; anxiety
Cannabis derivatives are among the most ancient and frequently consumed drugs. Cannabinoid dependence and selfadministration have been recently verified in animal tests (Tsou et al., 1995; Rodriguez de Fonseca et al., 1997; Martellotta et al., 1998; Tanda et al. 2000), further confirming that cannabinoids hold a considerable abuse potential (Abood and Martin, 1992). It is generally appreciated that the recreational use of cannabinoids is related to their positive modulatory effects on brain-rewarding processes along with their ability to positively influence emotional states and remove stress responses to environmental stimuli (Rodriguez de Fonseca et al., 1997) (for review, see Gardner and Vorel, 1998). Indeed, recent studies have shown that dopamine release is significantly increased in the nucleus accumbens after cannabinoid treatment presumably because of increased activity of dopaminergic neurons in the ventral tegmental area (Chen et al., 1990; Tanda et al., 1997). In addition, cannabinoid exposure

\footnotetext{
Received June 15, 2001; revised Sept. 12, 2001; accepted Sept. 20, 2001.

This work was supported by the Howard Hughes Medical Institute, National Institutes of Health (NIH) Grant NS 30549, and OTKA Grant T032251 (T.F.F.), NIH Grants DA 00286 and DA 11322 (K.M.), and Bolyai Fellowship (L.A., N.H.). C.L. is Chercheur Qualifié of the Fonds National de la Recherche Scientifique. Monoclonal antibody \#9303 raised against CCK was kindly provided by CURE/ Gastroenteric Biology Center, Antibody/RIA Core, NIH Grant DK 41301. We are grateful to K. Lengyel, E. Oszwald, and Gy. Goda for excellent technical assistance and to J. Haller for the critical reading of this manuscript.

Correspondence should be addressed to Tamás F. Freund, Institute of Experimental Medicine, Hungarian Academy of Sciences, Budapest, P. O. Box 67, H-1450, Hungary. E-mail: freund@koki.hu.

Copyright (C) 2001 Society for Neuroscience $\quad 0270-6474 / 01 / 219506-13 \$ 15.00 / 0$
}

decreases corticotropin-releasing hormone level in the amygdala, which may account for the reduced stress responses (Rodriguez de Fonseca et al., 1997).

The neuronal cannabinoid receptor CB1 has been shown to be responsible for most behavioral effects of cannabinoids (Ledent et al., 1999; Zimmer et al., 1999). Accordingly, CB1 knock-out animals do not develop cannabinoid dependence or selfadministration (Ledent et al., 1999). CB1 receptors are widely distributed in the brain (Tsou et al., 1998), suggesting that several brain areas may be affected by cannabinoids and contribute to their behavioral effects and abuse potential. Remarkably, in situ hybridization and immunocytochemical studies reported lowlevel, or even lack of CB1 receptors in the nucleus accumbens and in the ventral tegmental area, whereas other brain regions, like the prefrontal cortex, the hippocampus, and the amygdala, which densely innervate the nucleus accumbens, show moderate to very high CB1 receptor levels (Mailleux and Vanderhaeghen, 1992; Matsuda et al., 1993; Tsou et al., 1998; Egertova and Elphick, 2000). This strongly implies that indirect rather than direct modulation of the mesolimbic dopaminergic pathway (French et al., 1997; Tanda et al., 1997) may be responsible for CB1 receptormediated cannabinoid actions in reward processes and emotional responses.

Thus, to understand how cannabinoids modulate emotional states, one should consider that other brain regions may also play important roles in different aspects of these phenomena and elucidate the role of $\mathrm{CB} 1$ receptors at the synaptic, cellular, and 
network levels in these regions. In the present study, we aimed to determine the precise anatomical localization of CB1 receptors together with their physiological role in GABAergic synaptic transmission in the amygdala, which is a candidate region to be linked with the effects of cannabinoids on emotionally relevant behaviors. We investigated the regional distribution of CB1 receptors in the 13 different amygdala nuclei, then determined which cellular elements of the amygdaloid networks express the receptor, and finally, in parallel with the subcellular localization pattern, we analyzed the role of $\mathrm{CB} 1$ receptors in presynaptic modulation of GABAergic postsynaptic currents.

\section{MATERIALS AND METHODS}

Immunocytochemistry. All immunostainings were performed according to the protocols described in our previous papers (Katona et al., 1999, 2000). Briefly, 10 male Wistar rats (250-300 gm), three wild-type mice, and three CB1 receptor knock-out mice were perfused through the left ventricle by a fixative containing $4 \%$ paraformaldehyde, $0.2 \%$ picric acid, and $0.1 \%$ glutaraldehyde in $0.1 \mathrm{M}$ phosphate buffer. After perfusion, the brain was removed from the skull, and coronal sections from the block containing the amygdala were cut into $60-\mu \mathrm{m}$-thick sections by a $\mathrm{Vi}$ bratome. After extensive washes, the sections were freeze-thawed over liquid nitrogen, blocked in $4 \%$ bovine serum albumin, and incubated in a rabbit anti-CB1 antiserum (1:5000; raised against the $\mathrm{C}$ terminus of the rat CB1 protein; Hájos et al. 2000) for $48 \mathrm{hr}$. Next, the sections were processed either for immunoperoxidase or immunogold stainings (Katona et al., 1999). Some of the sections containing immunogold staining for CB1 receptors were incubated by a mouse anti-cholecystokinin (CCK) antibody (1:3000; CURE Gastroenteric Biology Center, Los Angeles, CA), and the second immunostaining was developed by using the immunoperoxidase procedure. Thereafter, the sections were dehydrated in ascending alcohol series and embedded into Durcupan (ACM; Fluka, Buchs, Switzerland). For electron microscopic investigations, selected immunoreactive profiles and regions were photographed and resectioned by a Reichert ultramicrotome into $\sim 60$-nm-thick sections. These sections were then evaluated in a Hitachi 7100 electron microscope.

For the colocalization experiments, the rabbit anti-CB1 antiserum (1:3000) was mixed with either the mouse anti-CCK antibody (1:2000) or with a mouse anti-parvalbumin antibody (1:2000; Sigma, St. Louis, MO). Cy3-conjugated anti-rabbit IgG made in donkey (1:200) and FITCconjugated anti-mouse IgG made in goat (1:100; both from Jackson ImmunoResearch, West Grove, PA) were used as secondary antibodies. The specificity of each antisera used in this study has been confirmed by the company or laboratory of origin. In case of the CB1 antisera, the specificity was further confirmed by the lack of immunostaining in the CB1 knock-out mice (Fig. 1C).

Electrophysiology. Male Wistar rats $(15-23 \mathrm{~d}$ old; $n=17)$ were deeply anesthetized with sodium pentobarbital ( $70 \mathrm{mg} / \mathrm{kg}$, i.p.) and decapitated. Adult male mice (both CB1 wild-type and knock-out; $n=3$ each) were anesthetized with ether and then decapitated. After opening the skull, the brain was quickly removed and immersed into ice-cold modified artificial CSF (ACSF), which contained (in mM): $126 \mathrm{NaCl}, 2.5 \mathrm{KCl}, 26$ $\mathrm{NaHCO}_{3}, 0.5 \mathrm{CaCl}_{2}, 5 \mathrm{MgCl}_{2}, 1.25 \mathrm{NaH}_{2} \mathrm{PO}_{4}$, and 10 glucose. Coronal slices containing the lateral, basal, and central nuclei of the amygdala (300-350 $\mu \mathrm{m}$ in thickness) were prepared using a Lancer Series 1000 Vibratome. The slices were incubated in ACSF containing (in mM: 126 $\mathrm{NaCl}, 2.5 \mathrm{KCl}, 26 \mathrm{NaHCO}_{3}, 2 \mathrm{CaCl}_{2}, 2 \mathrm{MgCl}_{2}, 1.25 \mathrm{NaH}_{2} \mathrm{PO}_{4}$, and 10 glucose) for at least $1 \mathrm{hr}$ before recordings. The given amygdala nucleus, selected for an experiment, was first identified at low magnification. Then, whole-cell patch-clamp recordings were obtained at $35-37^{\circ} \mathrm{C}$ from neurons visualized by infrared differential interference contrast videomicroscopy (Zeiss Axioscope, Göttingen, Germany). During recordings, the majority of cells were filled with biocytin, and then biocytin was developed by the conventional immunoperoxidase method. After developing biocytin, the exact location of the cells was determined by light microscopy. The recordings were done in the central nucleus and in the basal and lateral nuclei. Differences in the drug effects were not observed between these latter two nuclei. In most cases the visualized cells carried several spines. According to previous studies, this morphological feature defines the principal cell type of the basolateral amygdala and the central nucleus (McDonald, 1982a,b, 1985). The physiological identification of cell types was not possible because the intrapipette solution used for recordings blocked several voltage-gated ion channels, thereby fundamentally changing the intrinsic physiological properties of the neurons.

In all experiments, slices were perf used with ACSF containing 2-3 mM kynurenic acid, to eliminate ionotropic glutamatergic transmission. Under these conditions, the recorded currents were completely and reversibly blocked by the $\mathrm{GABA}_{\mathrm{A}}$ receptor antagonist bicuculline methiodide $(10-30 \mu \mathrm{M} ; n=3$; data not shown). Patch electrodes were pulled from borosilicate glass capillaries with an inner filament (BF150-110-10; 1.5 $\mathrm{mm}$ outer diameter; Sutter Instruments, Novato, CA) using a Sutter P-87 puller, and had resistances of 3-6 M $\Omega$ when filled with the intracellular solution. The intracellular solution contained (in mM): $140 \mathrm{Cs}$-gluconate, $2 \mathrm{CsCl}, 2 \mathrm{MgCl}_{2}, 10$ HEPES, 5 QX-314, and $2 \mathrm{Mg}$-ATP, pH 7.2-7.3 adjusted with $\mathrm{CsOH}$; osmolarity $290-300 \mathrm{mOsm}$. In some experiments $0.5 \%$ biocytin was also included in the intracellular solution. Recordings of the stimulation-elicited currents were performed at a holding potential of $+15 \pm 10 \mathrm{mV}$, whereas the spontaneous and miniature currents were recorded at $+25 \pm 10 \mathrm{mV}$. Access resistance (between 4 and $15 \mathrm{M} \Omega$, compensated $75 \pm 5 \%$ ) were frequently monitored and remained constant $( \pm 20 \%)$ during the analyzed period. A patch pipette used as a stimulating electrode was filled with ACSF. The stimulation procedure consisted of a single 5-50 V voltage pulse, $100 \pm 20-\mu$ sec-wide, elicited every $10 \mathrm{sec}(0.1 \mathrm{~Hz})$ (BioStim; Supertech Ltd., Pécs, Hungary). Signals were recorded with an Axopatch 200B amplifier (Axon Instruments, Foster City, CA), filtered at 1-2 kHz (eight-pole Bessel; FLA-01; Cygnus Technology, Fredericton, Canada), digitized at $5-10 \mathrm{kHz}$ (LabPC+ analog-to-digital board; National Instruments, Austin, TX) and analyzed off-line with CDR or SCAN software (courtesy of J. Dempster, University of Strathclyde, Glasgow, UK). For determining the $\tau$ value for the decay phase, a single exponential decay curve was fitted to the averaged events with the equation, $y=a^{*} e^{-(t / \tau)}$. Student' paired $t$ test was used to compare the changes in the mean conductance and frequency after drug application. The cumulative distribution curves were compared using Kolmogorov-Smirnov two-sample test. In any statistical tests, $p<0.05$ was considered as a significant difference. Data are presented, as mean \pm SEM. All anatomical and electrophysiological experiments were conducted in accordance with the principles and procedures outlined in the National Institutes of Health Guide for the Care and Use of Laboratory Animals.

Reagents. CP55,940 was obtained from Tocris Cookson (Bristol, UK) and WIN55,212-2 was obtained from Research Biochemicals (Natick, MA); both were dissolved in DMSO (100 mM stock solution for both agonists). SR141716A (dissolved as $10 \mathrm{~mm}$ stock) was provided by the National Institute on Drug Abuse drug supply service. DMSO by itself had no effect on IPSCs up to $0.01 \%$ concentration $(n=3)$. Bicuculline and kynurenic acid were purchased from Sigma, and TTX was purchased from Alomone Labs (Jerusalem, Israel).

\section{RESULTS}

\section{Regional distribution of CB1 cannabinoid receptors in the amygdala}

To characterize the distribution of CB1 cannabinoid receptors in the different amygdala nuclei, we performed immunostainings by using an antiserum against the $\mathrm{C}$ terminus of the rat CB1 cannabinoid receptor (Hájos et al. 2000). The pattern of immunostaining clearly delineated certain amygdaloid nuclei, some exhibiting very high CB1 expression level, whereas others showed no immunoreactivity (Fig. $1 A$, Table 1 ). The staining pattern and intensity were homogenous within a given nucleus, and major differences were indistinguishable at the divisional level.

According to the most recent nomenclature of Pitkänen (2000), 13 different nuclei and cortical areas constitute the amygdala. Among these, the most striking CB1-immunostaining pattern was observed in the so-called deep nuclei, or by other more commonly used terminology, the basolateral complex, which consists of the lateral, the basal, and the accessory basal nuclei (Fig. 1A). For simplicity, from here we will refer to these nuclei as the basolateral complex (BLA), because no major anatomical or physiological differences were observed in this study among these nuclei. As an exception, the dorsal part of the dorsolateral division in the 

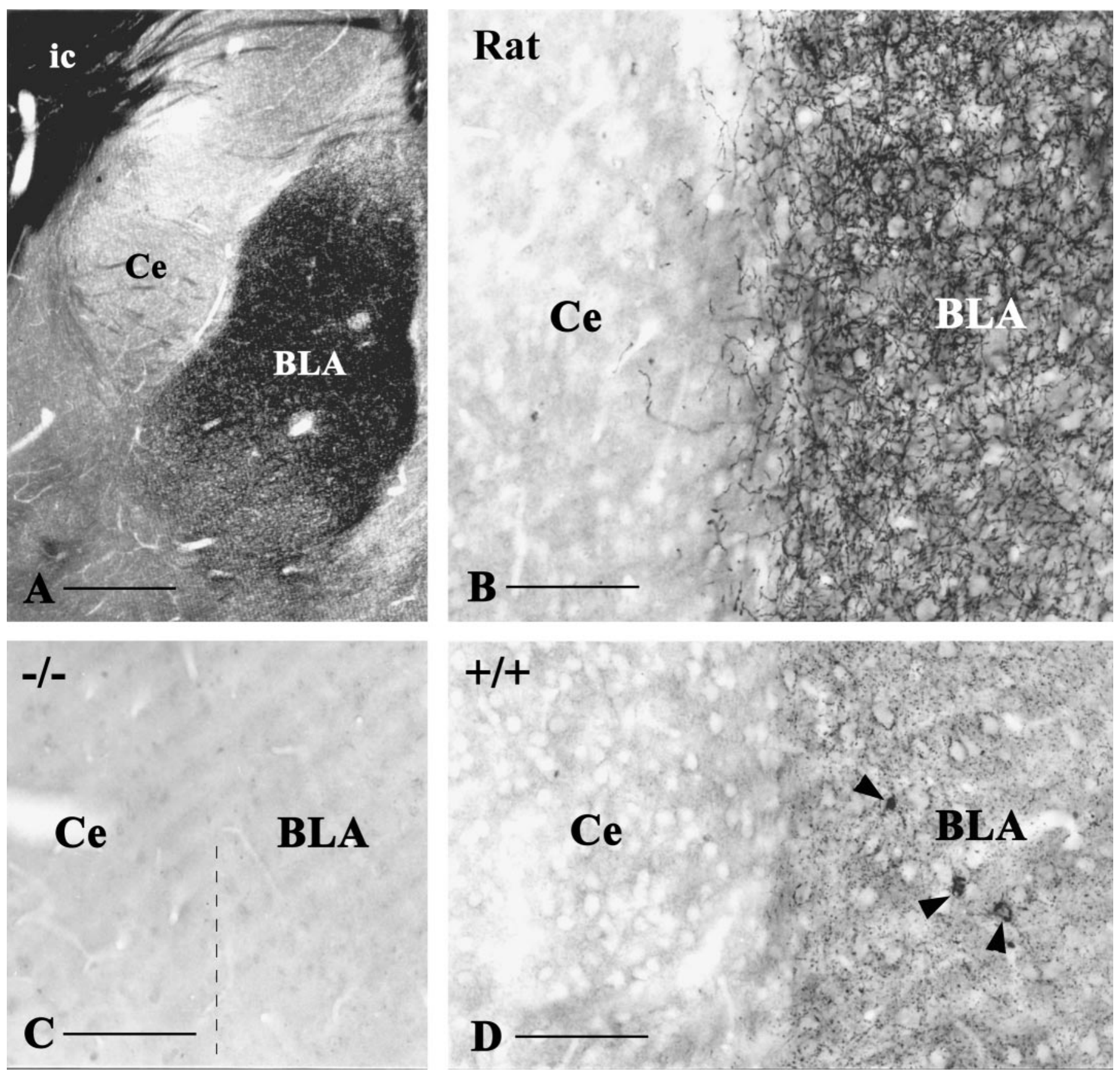

Figure 1. Regional localization of CB1 cannabinoid receptors in the rodent amygdala I. $A$, Low-power light micrograph of CB1 receptor immunostaining reveals selective distribution of CB1 receptors in certain amygdala nuclei of the rat. Whereas the basolateral complex of the amygdala $(B L A)$ shows very strong immunoreactivity, the central nucleus $(C e)$ is immunonegative for CB1 receptors. The micrograph was taken at bregma -2.5 . $B$, At high magnification, dense CB1 receptor-immunoreactive axonal meshwork is visible only in the basolateral complex but not in the central nucleus. $C$, Immunostaining for $\mathrm{CB} 1$ receptor in $\mathrm{CB} 1-/-$ mice gives rise to no staining at all, which confirms the selectivity of the antibody for CB1 receptors. $D$, In contrast, $\mathrm{CB} 1+/+$ mice have identical $\mathrm{CB} 1$ receptor localization pattern to rats. CB1 receptor-immunopositive axons clearly delineate the border between the basolateral complex and the central nucleus as in rats. Note the lack of dendritic labeling of CB1-immunoreactive neurons (arrowheads). $B L A$, Basolateral complex of the amygdala; $C e$, central nucleus of the amygdala; $i c$, internal capsule. Scale bars: $A, 500 \mu \mathrm{m} ; B-D, 100 \mu \mathrm{m}$.

lateral nucleus showed less dense staining than the other divisions (Fig. 1A), which, however, might be because of the reduced cell density in the dorsal tip of the lateral nucleus. Dense labeling was also found in the nucleus of the lateral olfactory tract, in the periamygdaloid cortex, as well as in the amygdalohippocampal area (Fig. 2, Table 1). The most prominent features of CB1 immunostaining in these heavily labeled nuclei were the dense meshwork of varicose axon collaterals (Fig. $1 B$ ) and the frequent occurrence of CB1-immunopositive cell bodies. The axon collaterals carried several boutons, and the largest ones formed spectacular basket-like arrays around CB1-immunonegative somata. In contrast to the axonal immunostaining, we found a complete lack of dendritic immunostaining in all amygdala nuclei.

In addition to the strongly labeled nuclei, modest immunostaining was found in the bed nucleus of the accessory olfactory tract and in the anterior and posterior cortical nucleus (Fig. 2, Table 1) 


\begin{tabular}{|c|c|c|c|}
\hline & Nucleus & Division & $\begin{array}{l}\text { Density of axona } \\
\text { immunostaining }\end{array}$ \\
\hline \multirow{8}{*}{$\begin{array}{l}\text { Deep nuclei } \\
\quad \text { (basolateral complex) }\end{array}$} & \multirow[t]{3}{*}{ Lateral nucleus } & Dorsolateral & + \\
\hline & & Ventrolateral & ++ \\
\hline & & Medial & ++ \\
\hline & \multirow[t]{3}{*}{ Basal nucleus } & Magnocellular & ++ \\
\hline & & Intermediate & ++ \\
\hline & & Parvicellular & ++ \\
\hline & \multirow[t]{2}{*}{ Accessory basal nucleus } & Magnocellular & ++ \\
\hline & & Parvicellular & ++ \\
\hline \multirow[t]{10}{*}{ Superficial nuclei } & Nucleus of the lateral olfactory tract & & ++ \\
\hline & Bed nucleus of the accessory olfactory tract & & + \\
\hline & Anterior cortical nucleus & & + \\
\hline & \multirow[t]{3}{*}{ Medial nucleus } & Rostral & - \\
\hline & & Central & - \\
\hline & & Caudal & - \\
\hline & \multirow[t]{3}{*}{ Periamygdaloid cortex } & Periamygdaloid cortex & ++ \\
\hline & & Medial & ++ \\
\hline & & Sulcal & ++ \\
\hline & Posterior cortical nucleus & & + \\
\hline \multirow[t]{8}{*}{ Other amygdaloid areas } & Anterior amygdaloid area & & - \\
\hline & \multirow[t]{4}{*}{ Central nucleus } & Capsular & - \\
\hline & & Lateral & - \\
\hline & & Intermediate & - \\
\hline & & Medial & - \\
\hline & \multirow[t]{2}{*}{ Amygdalo-hippocampal area } & Medial & ++ \\
\hline & & Lateral & ++ \\
\hline & Intercalated nuclei & & - \\
\hline
\end{tabular}

The density of axonal immunostaining in the given amygdaloid nuclei and division is expressed as follows:,++ high;,+ moderate; and,- absent.

which consisted mainly of axons, but in a much lower density. CB1-positive cell bodies were found only occasionally. The remaining nuclei, namely the anterior amygdaloid area, the central nucleus, the medial nucleus, and the intercalated nuclei proved to be immunonegative for $\mathrm{CB} 1$ receptor (Figs. $1 A, B, 2)$. Interestingly, those amygdaloid nuclei, which show a cortical-like neuronal architecture, expressed CB1 receptor similarly to the hippocampus and to the neocortex, whereas amygdaloid nuclei with a striatal-like architecture were devoid of CB1 immunostaining.

To confirm the specificity of the above staining pattern and our antiserum, we repeated immunostaining for $\mathrm{CB} 1$ receptor in wild-type and CB1 knock-out mice. Although the overall distribution pattern of CB1 receptors in the amygdala of the wild-type mice was identical to the rat amygdala (Fig. $1 D$ ), specific immunostaining was not found in the knock-out mice (Fig. $1 C$ ).

\section{Cellular expression pattern of CB1 cannabinoid receptors in the amygdala}

To understand the physiological role of CB1 receptors in the amygdala, it is important to elucidate which elements of the amygdaloid networks express the receptor protein. In this experiment, we concentrated our efforts on the basal nucleus, which is the most investigated and well described region of the amygdala. The distribution of CB1-immunostained somata (i.e., they were scattered and rather less numerous compared with principal cells) suggested that $\mathrm{CB} 1$ receptors might be expressed by GABAergic interneurons. Thus, double immunofluorescence stainings were performed for CB1 receptors and for two of the most characteristic neurochemical markers of different GABAergic cell popula- tions in the amygdala, namely the calcium-binding protein parvalbumin (PV) and the neuropeptide CCK (McDonald and Pearson, 1989; Kemppainen and Pitkänen, 2000).

Most of the CB1-expressing cells were also positive for CCK, whereas none of them contained parvalbumin (Fig. 3). Within the basal nucleus, 22 of 25 CB1-positive interneurons were also positive for CCK $(88 \%)$ (Fig. $3 A, B)$. In contrast, in a randomly selected population of 50 CB1-positive cell bodies, we found no PV immunoreactivity (Fig. 2C,D). When PV-positive cells were investigated $(n=56)$, the complete lack of colocalization was confirmed. In an earlier study, CCK-immunoreactive neurons were found to be heterogeneous according to morphological criteria (McDonald, 1985). Interestingly, this heterogeneity was also reflected in their CB1 receptor content (Fig. 3A,B). Of 33 so-called large CCK-positive cells, 32 were also found to be CB1-positive, whereas none of the so-called small CCK-positive cells $(n=22)$ expressed CB1.

To extend these findings obtained in the basal nucleus, we also investigated the $\mathrm{CB} 1$ receptor expression pattern related to $\mathrm{CCK}$ immunoreactivity in the nucleus of the lateral olfactory tract (NLOT) and in the amygdalohippocampal area (AHA), because these amygdala regions also showed particularly dense CB1 labeling. All CB1-positive cells were found to be CCK-positive both in the NLOT $(n=12)$ and in the AHA $(n=8)$. Moreover, only the large CCK-positive cells contained CB1 (NLOT, 16 of 19; AHA, 13 of 14), but none of the small CCK-positive cells $(n=16$; for both NLOT and AHA). 

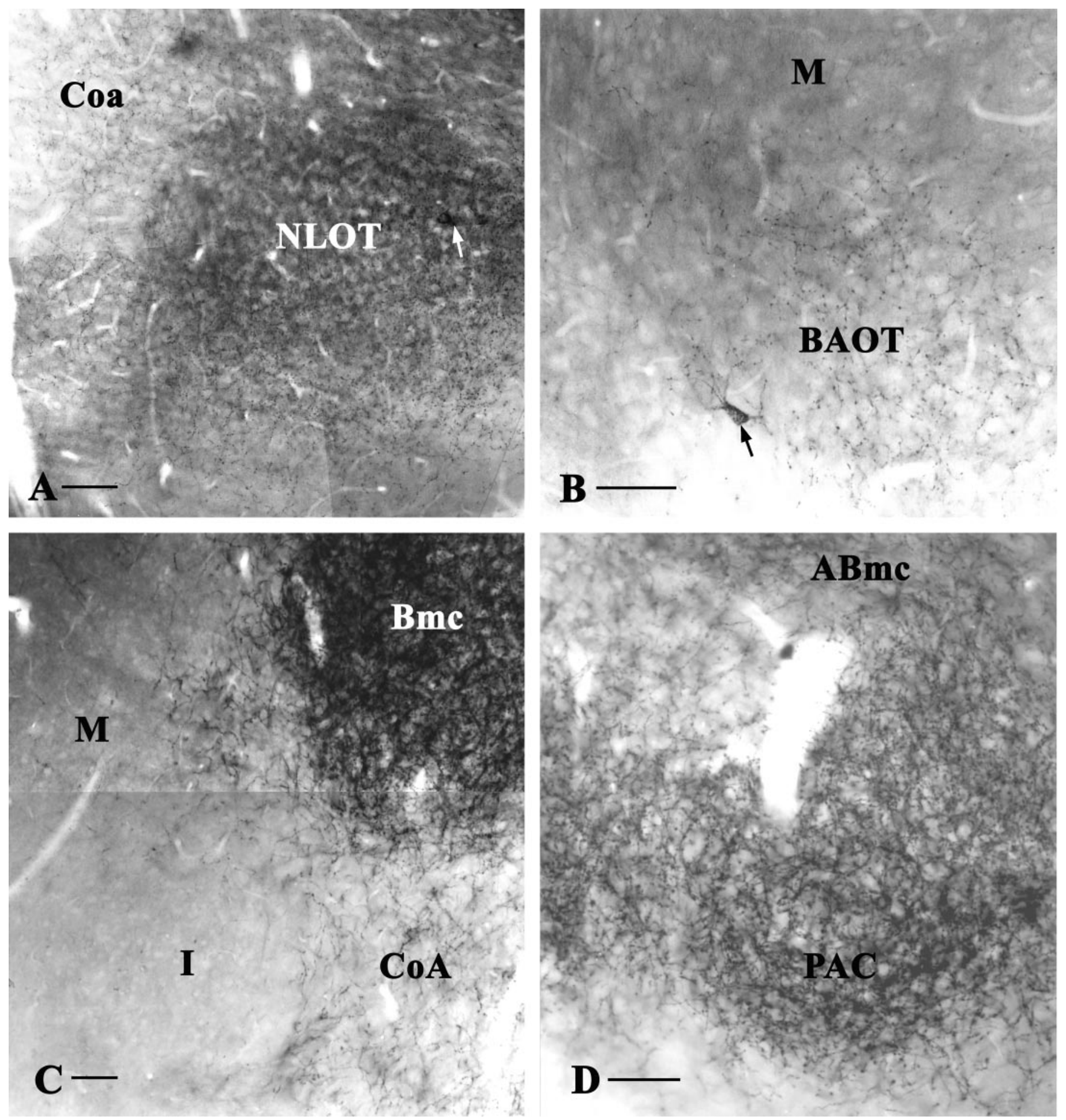

Figure 2. Regional localization of CB1 cannabinoid receptors in the rodent amygdala II. Four rostrocaudal levels are presented showing the characteristic distribution pattern of CB1 receptors in the rat amygdala. A, At the frontal level, the nucleus of the lateral olfactory tract (NLOT) is highly immunostained for CB1 receptors, whereas the anterior cortical nucleus $(\mathrm{Coa})$ contains only a moderate density of axons. The white arrow indicates a CB1-positive cell body within the NLOT. The micrograph was taken at bregma -1.3 . $B$, Although the medial nucleus $(M)$ shows no labeling for CB1, the bed nucleus of the accessory olfactory tract $(B A O T)$ contains moderate number of CB1-immunopositive axons and occasionally cell bodies as well (arrow). The micrograph was taken at bregma -2.1. $C$, One of the most strongly labeled nucleus for CB1 receptor is the basal nucleus and its magnocellular division $(B m c)$. In comparison, only few axons are visible in the caudal end of the anterior cortical nucleus (Coa), and there is a lack of CB1 immunostaining in the medial $(M)$ and in the intercalated nucleus $(I)$. The micrograph was taken at bregma -2.9 . $D$, More caudally, the strongest $\mathrm{CB} 1$ immunoreactivity is visible in the periamygdaloid cortex $(P A C)$ and in the accessory basal nucleus magnocellular division $(A B m c)$. The picture was taken at bregma -3.4 . Scale bars: $A, 200 \mu \mathrm{m} ; B-D, 50 \mu \mathrm{m}$. 

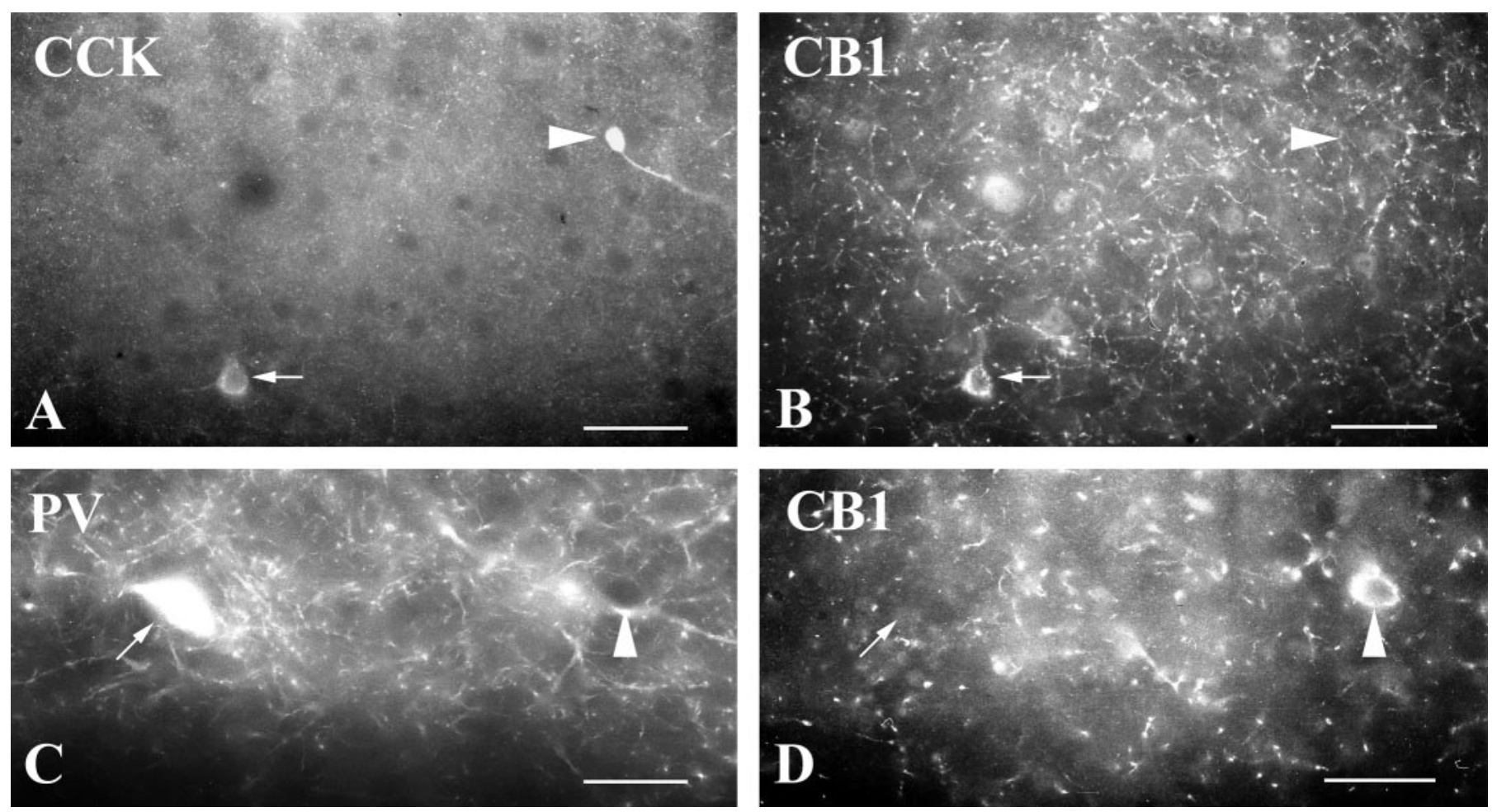

Figure 3. CB1 receptor is expressed by a selective subpopulation of cholecystokinin-immunoreactive interneurons in the basolateral complex of the amygdala. $A$, Immunofluorescence staining for cholecystokinin $(C C K)$ in the basal nucleus reveals two types of CCK-immunoreactive interneurons. The arrow depicts a so-called large CCK-positive cell, whereas the arrowhead points to a small CCK-immunoreactive neuron. $B$, Double-immunofluorescence staining demonstrates that the large CCK-positive cell expresses CB1 receptor (arrow), in contrast to the small CCK-immunoreactive neuron (arrowhead), which is negative for CB1. $C-D$, A parvalbumin $(P V)$-immunoreactive interneuron in the basal nucleus $(C$, arrow) is also negative for CB1 receptor (D, arrow), and CB1 receptor-immunoreactive cells do not contain parvalbumin, as indicated by arrowheads in $C$ and $D$. CCK, Cholecystokinin; $C B 1, \mathrm{CB} 1$ cannabinoid receptor; $P V$, parvalbumin. Scale bars, $50 \mu \mathrm{m}$.

\section{Subcellular localization of CB1 cannabinoid receptors in the amygdala}

The lack of dendritic CB1 immunostaining along with the dense meshwork of CB1-positive axon collaterals indicated that the functional localization site of CB1 receptor is predominantly presynaptic, as we have previously shown in the hippocampus (Katona et al., 1999, 2000; Hájos et al. 2000). To confirm the lack of somatodendritic membrane staining, we performed preembedding immunogold staining and analyzed CB1-immunoreactive cell bodies from the basal nucleus of two rats at the electron microscopic level (Fig. 4). The distribution of immunogold particles, representing the localization of $\mathrm{CB} 1$ receptors, was restricted to the intracellular membrane compartments within the cell body (Fig. 4A). Several immunogold particles were attached to the rough endoplasmic reticulum and to the Golgi complex (Fig. 4A), indicating that the antiserum recognizes the CB1 receptor protein during its synthesis and/or maturation. The gold particles were always attached to the outer surface of intracellular membrane-limited structures, in accordance with the fact that our antiserum was generated against the $\mathrm{C}$ terminus of the $\mathrm{CB} 1$ receptor protein.

In addition to the membrane compartments participating in protein synthesis and sorting, we also found localization of CB1 receptor on multivesicular bodies (MVB) (Fig. 4B), which are proposed to be involved in protein transport and/or degradation. The immunogold particles completely outlined the outer surface of the MVBs, but the inner vesicles were not labeled, probably because of the spherical constraints of the densely packed MVB.
In contrast to the intracellular membrane compartments, gold particles could not be found on the plasmamembrane of the cell body and the proximal dendrites (Fig. $4 A$ ).

The dense axonal immunostaining observed at the light microscopic level suggests a predominantly presynaptic localization of $\mathrm{CB} 1$ receptors. Indeed, detailed analysis of CB1 receptor immunostaining in three rats at the electron microscopic level confirmed this prediction (Fig. 5). Several CB1-positive axon terminals were identified and followed through serial sections, and they contained numerous gold particles attached to the inner surface of the plasmamembrane (Fig. 5A,B). The CB1-immunoreactive axon terminals formed symmetrical, presumably GABAergic synapses either on somata or on dendritic shafts. Boutons, forming two synapses next to each other and interrupted by an intrusion into the postsynaptic profile, were also found, similar to $\mathrm{CCK} /$ CB1-positive boutons described in the dentate gyrus (Acsády et al. 2000).

Because CB1 receptors were expressed by a selective subpopulation of CCK-immunoreactive local-circuit neurons, CB1positive axon terminals might also contain CCK. Indeed, combined immunogold (for CB1) and immunoperoxidase (for CCK) stainings verified this hypothesis (Fig. $5 D, E$ ) (sections from three rats were analyzed). All evaluated CB1-positive axon terminals and preterminal segments were also immunoreactive for CCK $(n=36)$, and they formed exclusively symmetrical synapses. In agreement with the light microscopical findings at the cellular level we also found several CCK-positive, but CB1-negative boutons. 
Figure 4. Distribution of CB1 cannabinoid receptors in the cell body is restricted to intracellular membrane compartments in the basal nucleus of the amygdala. $A$, Immunogold particles (small arrows), representing the localization of $\mathrm{CB} 1$ receptor protein, are always attached to the rough endoplasmic reticulum $(R E R)$ or to the Golgi apparatus $(G)$ in the cell body but never to the plasmamembrane (arrowheads). B, CB1 receptors are often found on the surface of multivesicular bodies $(M V B)$ or transport vesicles, indicating that the antibody recognizes $\mathrm{CB} 1$ protein that is packaged for transport to the axon terminals or is to be degraded. Scale bars: $A, 1 \mu \mathrm{m} ; B, 0.5 \mu \mathrm{m}$.
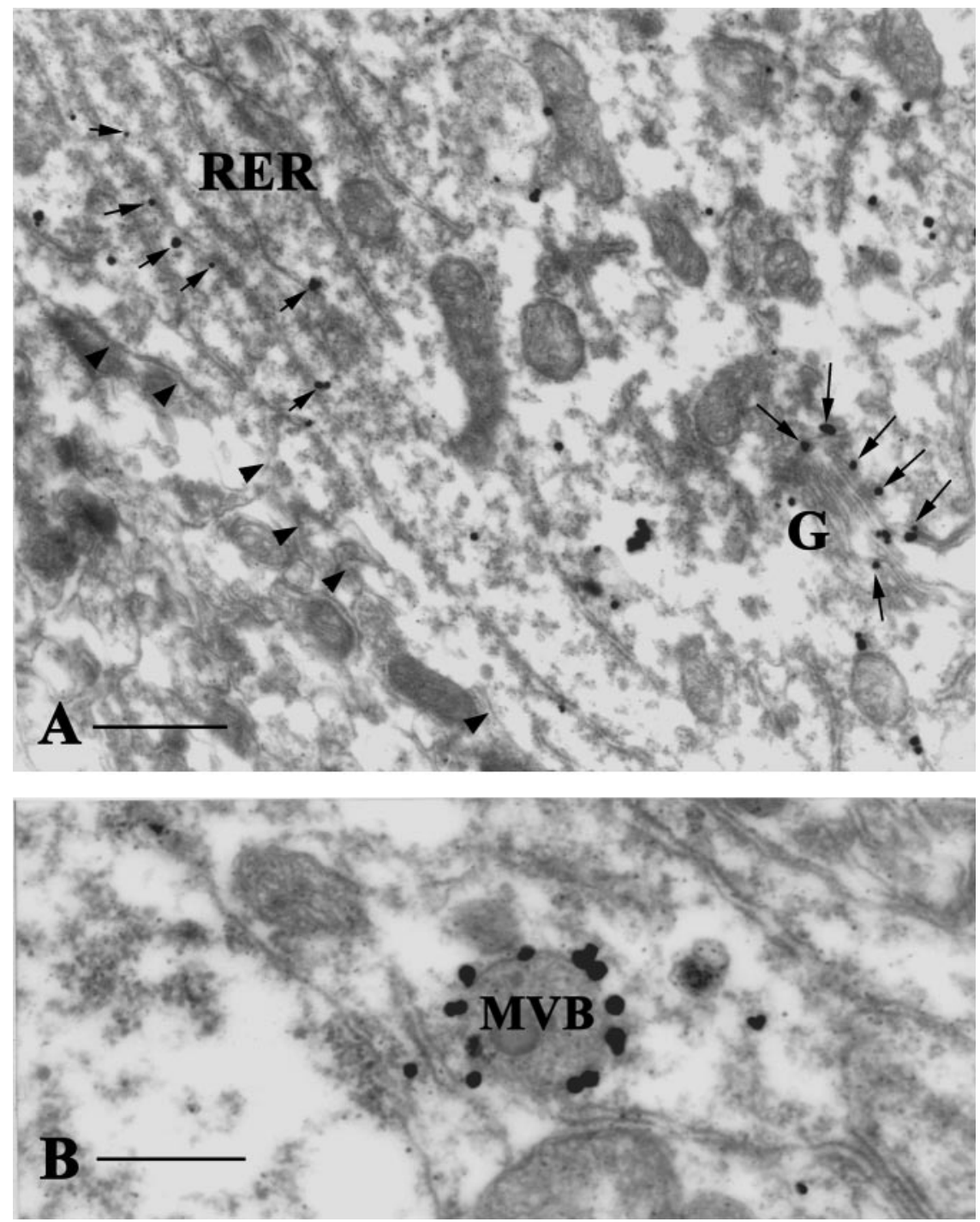

Although CB1-positive boutons labeled by the immunogold procedure formed exclusively symmetrical synapses indicating their GABAergic nature, some studies showed weak expression of $\mathrm{CB} 1$ receptor mRNA in non-GABAergic, presumably pyramidal cells of the basolateral complex (Matsuda et al., 1993; Marsicano and Lutz 1999). Because we could not confirm this observation at the cellular level, we focused our investigation to clarify whether boutons forming asymmetrical synapses contain sufficient quantity of $\mathrm{CB} 1$ protein to demonstrate the presence of $\mathrm{CB} 1$ receptors at glutamatergic synapses. Because the smaller size of glutamatergic boutons may be accompanied by reduced number of immunogold particles, the immunoperoxidase procedure was used in this experiment, because the diff usible nature of the dense end product of immunoperoxidase reaction usually results in entirely filled boutons, which are more easily detected (Fig. 5C).

Detailed quantification of immunoperoxidase staining on a randomly selected population of asymmetrical synapses from the basal nucleus of a rat showed that nearly all boutons forming asymmetrical synapses were negative for CB1 receptor (312 of 313) (Fig. 5C). Thus, the vast majority of glutamatergic synapses do not have CB1 receptors. On the other hand, nearly all CB1immunoreactive boutons evaluated on a different sample formed symmetrical synapses (67 of 71 ), and only 4 of 71 boutons (5.6\%) were found to give an asymmetrical-like synapse.

\section{CB1 receptor agonists depress monosynaptic evoked IPSCs in the basolateral complex, but not in the central nucleus of the amygdala}

The presynaptic localization of $\mathrm{CB} 1$ receptors on CCKimmunoreactive GABAergic interneurons suggests that cannabinoid action might alter inhibitory synaptic transmission in the amygdala. This hypothesis was tested by measuring the effects of the cannabinoid receptor agonists WIN55,212-2 and CP55,940 on electrically evoked IPSCs (eIPSCs) received by principal cells of the lateral and basal nuclei. Indeed, $1 \mu \mathrm{M}$ CP55,940 reduced the amplitude of eIPSCs to $59.4 \pm 5.9 \%$ of the control $(n=7 ; p<$ 0.05) (Table 2). After washing out the drug from the preparation, the amplitude of eIPSCs returned to the control level (98.9 \pm $5.3 \%$ of the control; $n=7 ; p>0.1$ ). Similarly, another potent synthetic cannabinoid, WIN55,212-2 (1 $\mu \mathrm{M})$, also significantly reduced the amplitude of eIPSCs $(61.1 \pm 5.9 \%$ of the control; $n=6 ; p<0.05$ ) (Table 2, Fig. 6A). This effect was reversed by applying the CB1 receptor antagonist SR141716A $(1 \mu \mathrm{M} ; 95.8 \pm$ $4,9 \%$ of the control; $n=4 ; p>0.1$ ) (Fig. $6 A$ ). Because a recent study found that SR141716A is not an exclusive CB1 receptor 

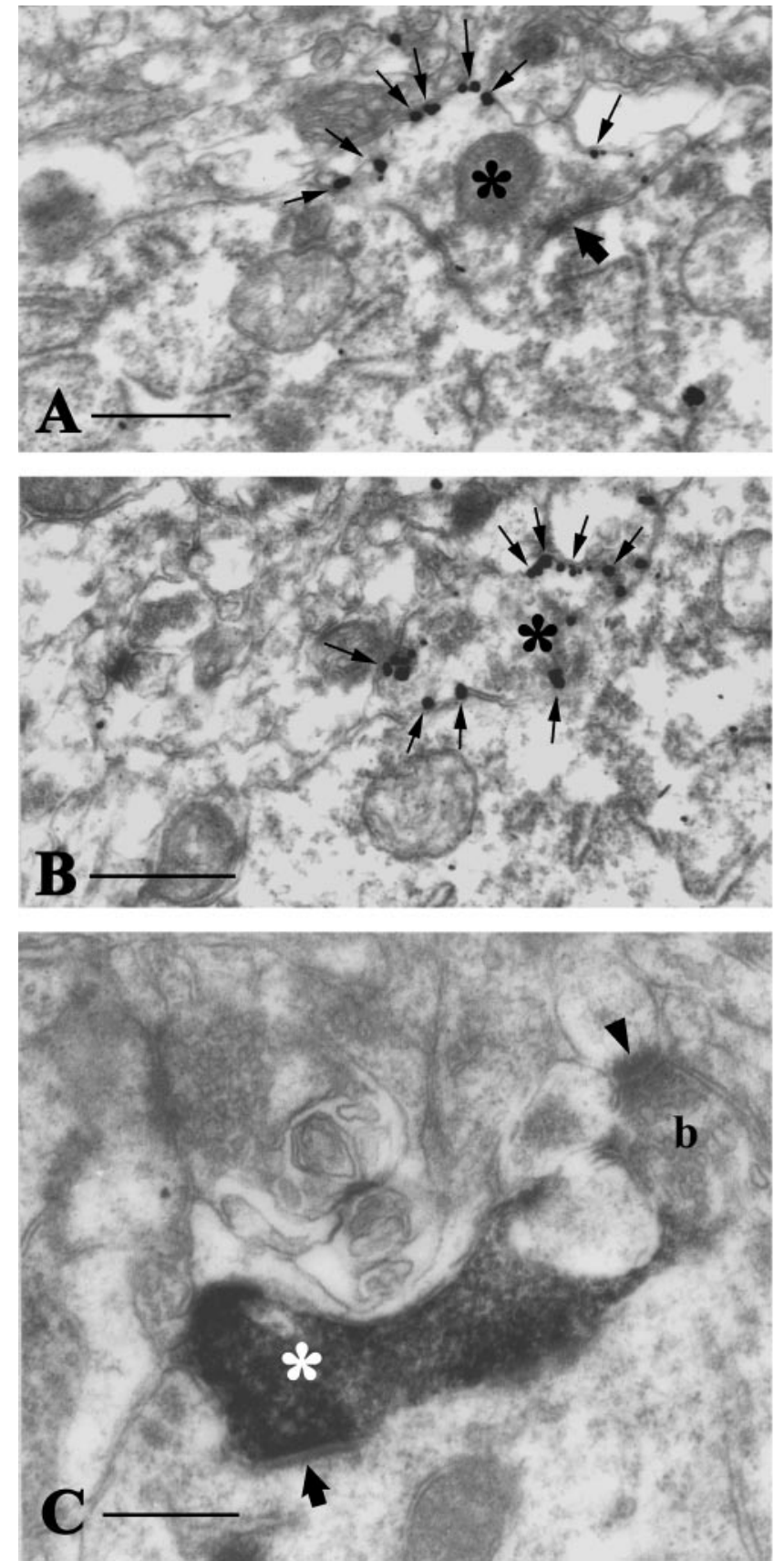
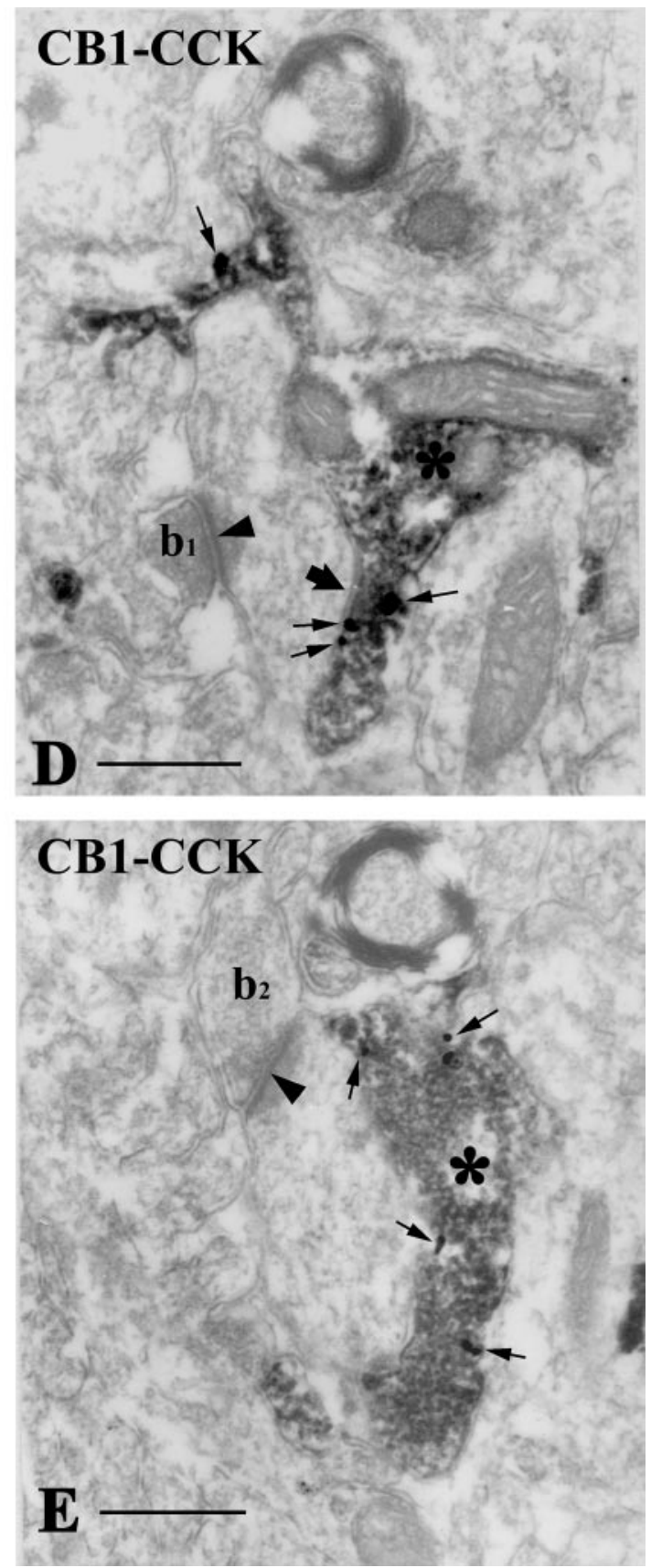

Figure 5. Presynaptic localization of CB1 cannabinoid receptors in the amygdala. $A, B$, Serial sections cut from a CB1-immunoreactive axon terminal (labeled by an asterisk) forming a symmetrical synapse (thick arrow) on a cell body in the basal nucleus of the amygdala. Note that gold particle labeling is restricted to the inner surface of the bouton, where the intracellular $\mathrm{C}$ terminus epitope of $\mathrm{CB} 1$ is located. $C$, High-power electron micrograph from the basal nucleus depicts that a CB1-immunoreactive bouton (white asterisk) forms a symmetrical synapse with its postsynaptic target. In this experiment, immunoperoxidase procedure was used taking advantage of its higher sensitivity. The black reaction product within the axon terminal demonstrates the CB1 immunopositivity of the bouton. In contrast, the complete lack of staining in an axon terminal $(b)$, forming asymmetrical synapse, suggests that glutamatergic axons do not contain CB1 receptors. $D$, E, Combined immunogold-immunoperoxidase double staining for CB1 receptor (gold particles labeled by small arrows) and CCK (the DAB end product of immunoperoxidase reaction is depicted by asterisk) confirms that the axon terminals of CCK-containing interneurons in the basal nucleus bear presynaptic CB1 receptors. Compare the CB1/CCK double-immunopositive bouton forming a symmetrical synapse (thick arrow) with the double-immunonegative axon terminals $\left(b_{1}, b_{2}\right)$, which give asymmetrical synapses (arrowheads) onto the same dendritic shaft. Scale bars: $A-E, 0.5 \mu \mathrm{m}$.

antagonist (Hájos et al. 2001), the previous experiments were repeated in wild-type and $\mathrm{CB} 1$ knock-out mice, to determine whether the effect of WIN55,212-2 was because of the activation of CB1 receptors. In wild-type mice, $1 \mu \mathrm{M}$ WIN55,212-2 depressed the amplitude of eIPSCs $(56.3 \pm 4.4 \%$ of the control; $n=$ $5 ; p<0.05$ ) (Table 2, Fig. $6 C$ ), but had no effect in the knock-out mice $(104.3 \pm 3.2 \%$ of the control; $n=5 ; p>0.1)$ (Table 2, Fig. 6D).

To test the physiological consequences of the regional differences in the distribution of CB1 receptors, we also analyzed the effect of $1 \mu \mathrm{M}$ WIN55,212-2 on eIPSCs in the central nucleus. In parallel with the anatomical findings, the cannabinoid agonist 
Table 2. Effect of cannabinoid agonists WIN55,212-2 (1 $\mu \mathrm{M}$, marked with $\left.{ }^{a}\right)$ and CP55,940 (1 $\mu \mathrm{M}$, marked with $\left.^{b}\right)$ on the amplitude of eIPSC recorded in rat BLA and $\mathrm{CA}$ or in the basolateral complex of wild-type $(\mathrm{CB} 1+/+)$ mice and knock-out $(\mathrm{CB} 1-/-)$ mice

\begin{tabular}{|c|c|c|c|c|c|}
\hline eIPSC & $n$ & species & Control & $\begin{array}{l}\text { Amplitude (pA) } \\
\text { CB1 agonist }\end{array}$ & Effect $\%$ \\
\hline BLA & 6 & Rat & $475.1 \pm 60$ & $305.8 \pm 66^{a}$ & $61.1 \pm 6^{*}$ \\
\hline BLA & 7 & Rat & $408.8 \pm 66$ & $235.7 \pm 35^{b}$ & $59.4 \pm 6^{*}$ \\
\hline $\mathrm{CA}$ & 5 & Rat & $337.4 \pm 30$ & $357.8 \pm 37^{a}$ & $105.7 \pm 3$ \\
\hline $\mathrm{CB} 1+/+$ & 5 & Mouse & $865.5 \pm 91$ & $487.1 \pm 81^{a}$ & $56.3 \pm 4^{*}$ \\
\hline CB1-/- & 5 & Mouse & $610.5 \pm 41$ & $635.2 \pm 49^{a}$ & $104.0 \pm 3$ \\
\hline
\end{tabular}

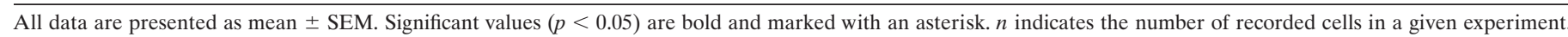

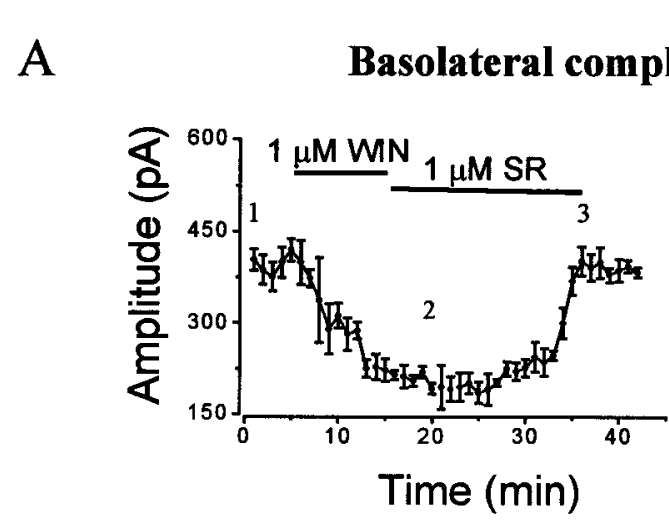

B

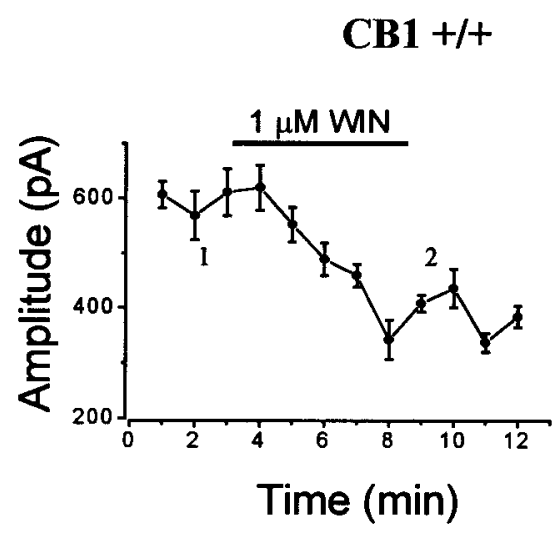

\section{RAT}

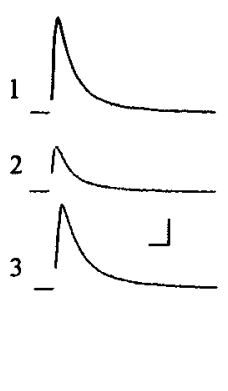

\section{Central nucleus}

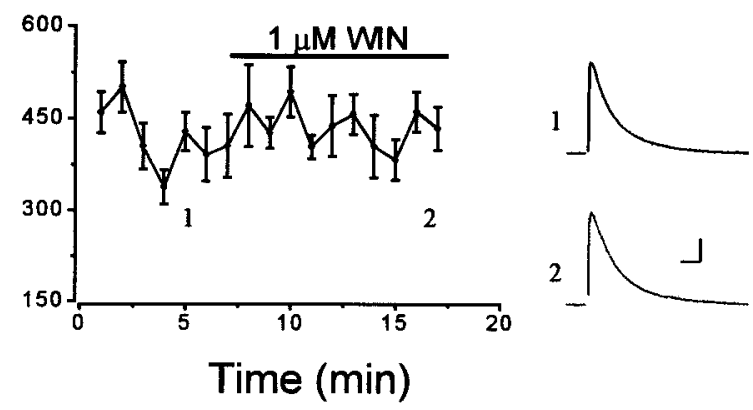

MOUSE

Basolateral complex $\quad$ CB1 -/-

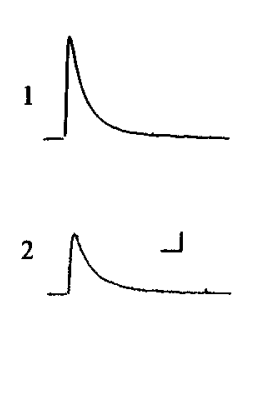

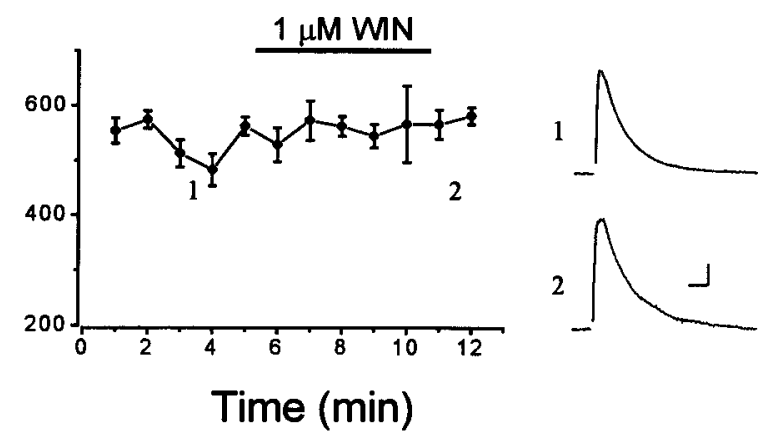

Figure 6. A synthetic cannabinoid agonist, WIN55,212-2, suppresses IPSCs in the basolateral complex of amygdala but not in the central nucleus. $A$, In rat, bath application of WIN55,212-2 (1 $\mu \mathrm{M})$ causes a 50\% reduction in the amplitude of monosynaptic IPSCs (eIPSCs) evoked in the basal nucleus (plot on the left) but not in the central nucleus of amygdala (plot on the right). Whole-cell patch-clamp recordings were obtained from spiny principal cells. The CB1 receptor antagonist SR141716A $(1 \mu \mathrm{M})$ reverses the decrement of eI PSC amplitude. $B$, The amplitude of eIPSCs is suppressed by CB1 receptor activation in the lateral nucleus of wild type $(\mathrm{CB} 1+/+)$ but not in $\mathrm{CB} 1-/-$ knock-out mice. IPSCs were evoked by focal microstimulation delivered via a patch pipette placed into the close vicinity of the cell. All data points on the plots represent a mean \pm SEM of six consecutive events. Inserts are average records of 6-10 consecutive IPSCs taken at the labeled time points. Stimulus artifacts were removed for clarity. Calibration: 10 msec, $100 \mathrm{pA}$.

failed to alter the amplitude of eIPSCs $(105.7 \pm 3.1 \%$ of the control; $n=5 ; p>0.1$ ) (Table 2, Fig. $6 B$ ).

\section{CB1 receptor activation suppresses action potential- driven IPSCs, but not miniature IPSCs in the basolateral complex}

To further examine the nature of cannabinoid action, the effect of WIN55,212-2 was compared on spontaneous (action potentialdriven) IPSCs (sIPSCs) and action potential-independent miniature IPSCs (mIPSCs). WIN55,212-2 (1 $\mu \mathrm{M})$ dramatically decreased the frequency of sIPSCs to $41.7 \pm 5.9 \%$ of the control value $(n=7 ; p<0.05)$ (Table 3 ). The conductance of sIPSCs was also decreased (88.2 $\pm 2.4 \%$ of control; $n=7 ; p<0.05)$. In the presence of the voltage-gated $\mathrm{Na}^{+}$-channel blocker tetrodotoxin $(0.5-1 \mu \mathrm{M})$ and the voltage-gated $\mathrm{Ca}^{2+}$-channel blocker $\mathrm{Cd}^{2+}$ $(200 \mu \mathrm{M})$, action potential- and $\mathrm{Ca}^{2+}$ influx-independent miniature IPSCs were also measured (Fig. 7B). The application of tetrodotoxin and $\mathrm{Cd}^{2+}$ decreased both the conductance and frequency of recorded IPSCs $(79.1 \pm 7.3$ and $39.0 \pm 5.8 \%$ of the control, respectively; $n=10-10 ; p<0.05)$. Under these conditions, neither the conductance $(94.9 \pm 2.7 \% ; n=10 ; p>0.1)$ nor 
Table 3. Effect of cannabinoid agonist WIN55,212-2 (1 $\mu \mathrm{M})$ on action potential-dependent SIPSCs

\begin{tabular}{lccc} 
sIPSC $(n=7)$ & Control & WIN & Effect $\%$ \\
\hline Conductance $(\mathrm{pS})$ & $1342.4 \pm 61$ & $1186.7 \pm 73$ & $\mathbf{8 8 . 2} \pm \mathbf{2}^{*}$ \\
Frequency $(\mathrm{Hz})$ & $8.5 \pm 2$ & $3.7 \pm 1$ & $\mathbf{4 1 . 7} \pm \mathbf{6}^{*}$ \\
\hline
\end{tabular}

Recordings were from spiny principal cells in the rat basolateral complex. All data are presented as mean \pm SEM. Significant values $(p<0.05)$ are bold and marked with an asterisk.

the frequency $(81.3 \pm 11.9 \% ; n=10, p>0.1)$ (Table 4$)$ of miniature IPSCs were significantly altered after application of 1 $\mu \mathrm{M}$ WIN 55212-2 (Fig. 7B). The decay kinetics of IPSCs remained unaffected by tetrodotoxin, $\mathrm{Cd}^{2+}$, or by WIN55,212-2 treatment $\left(\tau_{\mathrm{mIPSC}} / \tau_{\mathrm{sIPSC}} 99.0 \pm 3.5 \% ; n=10 ; p>0.1 ; \tau_{\mathrm{WIN}} /\right.$ $\left.\tau_{\text {mIPSC }} 101.1 \pm 3.7 \% ; n=10 ; p>0.1\right)($ Fig. $7 A, B)$, indicating the lack of postsynaptic effects.

\section{DISCUSSION}

Despite the well known effects of cannabinoids on emotional state and memory, previous studies have not yet investigated in detail how cannabinoids may affect neuronal networks in the amygdala. By combining anatomical and electrophysiological approaches, we found that (1) CB1 cannabinoid receptors are expressed selectively by a specific subpopulation of CCK-immunoreactive interneurons in certain amygdaloid nuclei, but are absent in other nuclei, (2) CB1 receptors are located presynaptically on axon terminals forming symmetrical synapses, and (3) after activation, CB1 receptors reduce the amplitude of the $\mathrm{Ca}^{2+}$-dependent IPSCs, but do not affect the $\mathrm{Ca}^{2+}$-independent miniature IPSCs recorded in principal cells of the lateral and basal nuclei.

\section{CB1 cannabinoid receptors at the synaptic level in the amygdala}

The significance of the localization and function of CB1 receptors at the synaptic level has been emphasized by recent discoveries in the hippocampus and cerebellum, suggesting that endocannabinoids may act as retrograde synaptic messengers on presynaptic CB1 receptors (Kreitzer and Regehr, 2001; Ohno-Shosaku et al., 2001; Wilson and Nicoll, 2001; Wilson et al., 2001). Our present findings that $\mathrm{CB} 1$ receptors are located presynaptically on axon terminals of specific elements of neuronal networks inhibiting the release of GABA suggest that similar mechanisms are likely to operate in the amygdala.

Both immunocytochemical procedures (i.e., immunogold and immunoperoxidase staining) revealed CB1 receptor localization on axon terminals forming symmetrical synapses typical of GABAergic boutons in most brain regions. In agreement with the

\section{A}
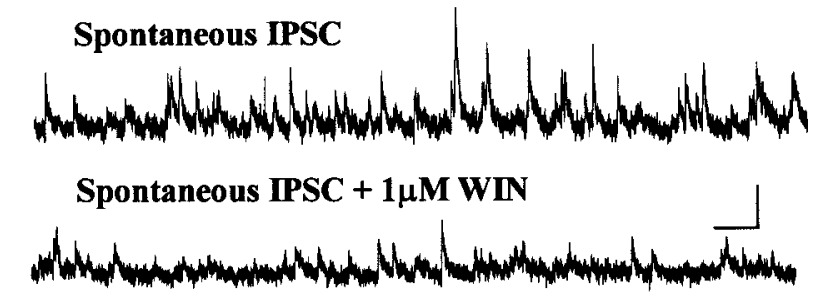

$\mathrm{B}$
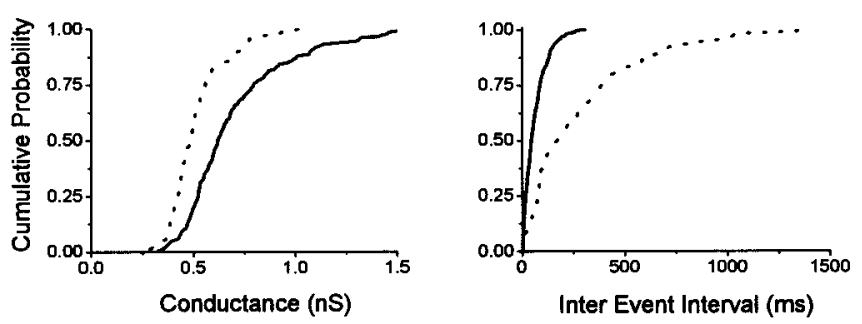

$\mathrm{C}$
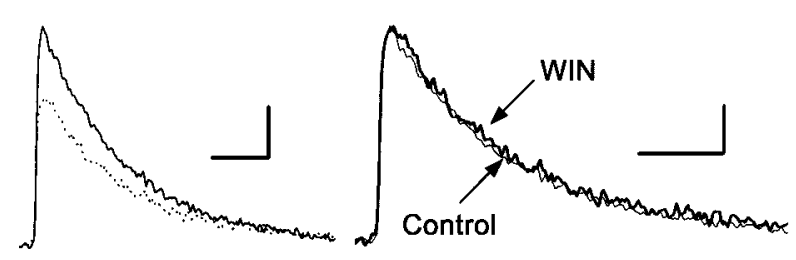

\section{Miniature IPSC (TTX, Cd $\left.{ }^{2+}\right)$}

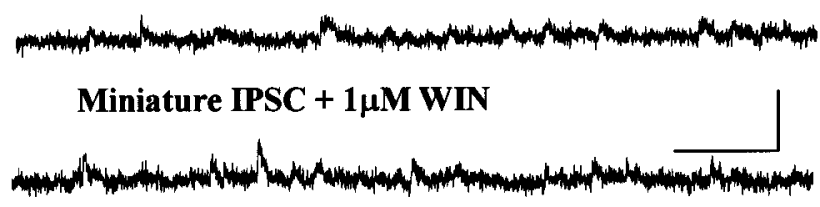

$\mathrm{E}$
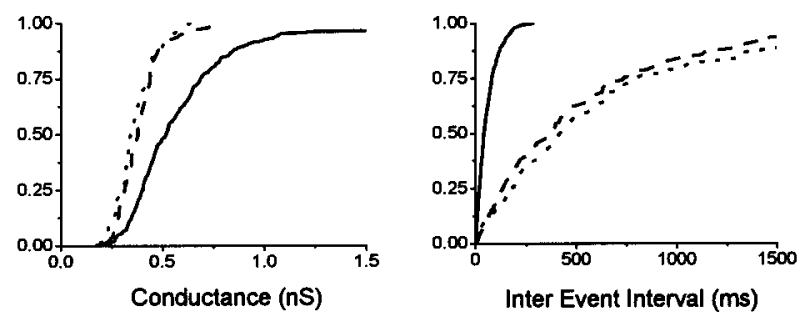

$\mathrm{F}$
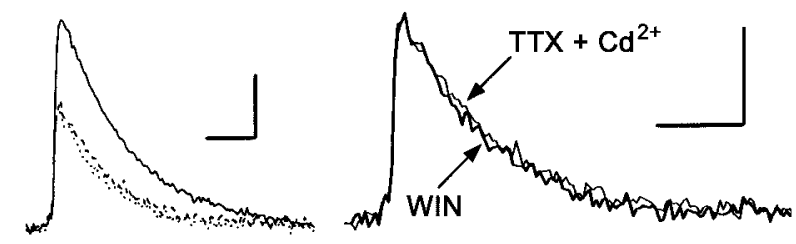

Figure 7. Action potential-driven IPSCs, but not $\mathrm{Ca}^{2+}$-influx-independent miniature events, are sensitive for CB1 receptor activation in the basal nucleus of the amygdala. $A$, Spontaneous, action potential-dependent IPSCs (sIPSCs) are suppressed by bath application of the CB1 receptor agonist WIN55,212-2 (1 $\mu \mathrm{M})$, as seen in the raw traces. $B$, Cumulative probability distributions of peak conductances and interevent intervals of sIPSCs are shown before (solid line; $n=231$ ) and after (dotted line; $n=88$ ) the application of $1 \mu \mathrm{M}$ WIN55,212-2. The CB1 receptor agonist decreases the conductance and increases the interevent intervals (i.e., decreases the frequency) of spontaneous IPSCs (control, $n=352$; WIN, $n=106$ ). Averages of sIPSCs are shown in $C$. When averaged events are scaled to the same peak value (on the right), no changes in the IPSC kinetics can be observed after WIN55,212-2 application. D, In the presence of TTX $(1 \mu \mathrm{M})$ and $\mathrm{Cd}^{2+}(200 \mu \mathrm{M})$, mIPSCs are unaltered after the bath application of $1 \mu \mathrm{M}$ WIN55,212-2, as shown on representative records. E, Application of TTX and $\mathrm{Cd}^{2+}$ significantly reduces both the conductance and the frequency (i.e., increases interevent intervals) of spontaneous IPSCs. The addition of CB1 receptor agonist causes no further changes in miniature IPSCs, as seen on the cumulative distribution plots of the conductance (control, solid line, $n=301$; TTX $+\mathrm{Cd}^{2+}$, dashed line, $n=96$; W IN, dotted line, $\left.n=76\right)$ and on the cumulative distribution plots of the interevent intervals (control, solid line, $n=502$; TTX $+\mathrm{Cd}^{2+}$, dashed line, $n=105$; WIN, dotted line, $n=89$ ). $F$, Averaged IPSCs for spontaneous IPSCs and miniature IPSCs are superimposed. The peak scaled mIPSCs (on the right) show no alterations in the kinetic parameters. Calibration: $A, D, 100 \mathrm{msec}, 100 \mathrm{pA} ; C, F, 5 \mathrm{msec}, 10 \mathrm{pA}$. 


\begin{tabular}{|c|c|c|c|}
\hline $\operatorname{mIPSC}(n=10)$ & Control & WIN & Effect $\%$ \\
\hline Conductance (pS) & $431.9 \pm 44$ & $409.7 \pm 38$ & $94.9 \pm 3$ \\
\hline Frequency (Hz) & $3.2 \pm 1$ & $2.6 \pm 0.21$ & $81.3 \pm 12$ \\
\hline$\tau$ of decay (msec) & $8.0 \pm 1$ & $8.1 \pm 1$ & $101.1 \pm 4$ \\
\hline
\end{tabular}

Recordings were from spiny principal cells in the rat basolateral complex. All data are presented as mean \pm SEM. No significant changes $(p<0.05)$ were observed.

anatomical data, electrophysiological recordings from principal cells of the lateral and basal nuclei showed that synthetic cannabinoids could significantly reduce the amplitude of $\mathrm{GABA}_{\mathrm{A}}$ receptor-mediated evoked IPSCs in the amygdala. Moreover, the lack of cannabinoid effects on eIPSCs in the CB1 receptor knockout animals confirmed the involvement of $\mathrm{CB} 1$ receptors in this process. In addition, spontaneous, action potential-driven IPSCs were also altered after cannabinoid application. However, mIP$\mathrm{SCs}$ recorded in the presence of voltage-gated $\mathrm{Na}^{+}-$and $\mathrm{Ca}^{2+}$ channel blockers were not changed, probably because of the fact that $\mathrm{CB} 1$ receptors reduce GABA release via blockade of presynaptic N-type $\mathrm{Ca}^{2+}$-channels (Wilson et al., 2001). These results are in agreement with previous findings obtained in the hippocampus, which show presynaptic CB1 receptor localization on GABAergic axon terminals along with the inhibition of GABA release (Katona et al., 1999, 2000; Hájos et al., 2000; Hoffman and Lupica, 2000; Irving et al., 2000). Presynaptic inhibition of GABA release by cannabinoids has been proposed in several other brain regions as well (Chan et al., 1998; Szabó et al., 1998; Vaughan et al., 1999, 2000; Takahashi and Linden, 2000; Hoffman and Lupica, 2001). Taken together, we suggest that the role of endocannabinoids as retrograde synaptic signals modulating GABAergic transmission is widespread throughout the CNS. Our results indicate that if endocannabinoids are released by postsynaptic principal cells in certain nuclei of the amygdala, then these cells will be able to modulate their own GABAergic inputs according to their actual activity pattern.

\section{CB1 cannabinoid receptors at the network level in the amygdala}

Interestingly, not only the presynaptic localization of CB1 receptors and its physiological consequences, but also their distribution pattern at the network level seems to be conserved across different forebrain regions. Previous immunocytochemical studies in the hippocampus have demonstrated that CB1 receptors are expressed by a specific interneuron population, characterized by the expression of cholecystokinin (Katona et al., 1999; Tsou et al., 1999). In addition, high expression level of CB1 receptor mRNA was also reported to colocalize with CCK mRNA in the neocortex, entorhinal cortex, hippocampus, and amygdala (Marsicano and Lutz, 1999). By showing that this colocalization exists at the protein level in several amygdaloid nuclei, our studies provide further evidence that CB1 receptors occupy a strikingly consistent location and subserve specific roles throughout several forebrain region.

In the amygdala, these large CCK-positive cells are GABAergic interneurons and densely innervate pyramidal cells (McDonald and Pearson, 1989). Interestingly, electrophysiological studies reported strong tonic inhibitory control over the activity of pyramidal cells, which was proposed to account for their very low spontaneous activity observed in in vivo recordings (Takagi and Yamamoto, 1981; Rainnie et al., 1991; Paré and Gaudreau, 1996;
Collins and Paré, 1999). Thus, pyramidal cells in the basolateral amygdala receiving specific excitatory sensory inputs may need to remove this tonic inhibitory control to be able to fire and undergo synaptic plasticity to create associations between emotionally relevant and neutral stimuli, as in Pavlovian fear conditioning, where the basolateral complex is supposed to play a crucial role (LeDoux, 2000). We propose that a possible way to remove the tonic inhibitory control may be the release of endocannabinoids after powerful excitatory impact induced by stimuli with strong emotional values. Removal of inhibition may provide a specific time window for synaptic modification of other afferent inputs and lead to the formation of appropriate associations. Indeed, the well known panic syndrome induced by exposure to high doses of cannabinoids (Abood and Martin, 1992), where even a neutral stimulus may exert a fear response, may well be one interesting behavioral consequence of these inappropriate associations in the amygdala.

\section{Behavioral consequences of $\mathrm{CB} 1$ receptor activation in the amygdala}

One of the most important and controversial psychopharmacological features of cannabinoids is their abuse potential (Abood and Martin, 1992). Two major behavioral phenomena were supposed to account for this effect, both are strongly related to the amygdala. On one hand, cannabinoids have been postulated to modulate reward mechanisms (Gardner and Vorel, 1998), and, as most abused drugs, they can enhance dopamine release in the nucleus accumbens (NAC) (Chen et al., 1990; Tanda et al., 1997). Surprisingly, cannabinoids are not able to increase dopamine efflux in acute NAC slice preparations (Szabó et al., 1999), and CB1 receptors are absent or very few in the ventral tegmental area (Mailleux and Vanderhaeghen, 1992; Tsou et al., 1998; Egertova and Elphick, 2000), where the mesolimbic dopaminergic pathway originates. These findings indicate that those forebrain regions that project to the NAC may be indirectly involved in the elevation of dopamine level in vivo. Indeed, the amygdaloaccumbens pathway was shown to play a key role in stimulusreward associations (Cador et al., 1989; Everitt et al., 1991) and in affective perception-induced increase of dopamine release in the NAC (Louilot and Besson, 2000). Moreover, during the presentation of rewarding stimuli, glutamatergic neurons in the basolateral amygdala increase their activity (Muramoto et al., 1993), which evoke an elevation in dopamine efflux in the NAC via the activation of presynaptic glutamate receptors on dopaminergic axon terminals (Floresco et al., 1998). Our results suggest that cannabinoids may reduce the tonic GABAergic inhibitory control over pyramidal cells in the basolateral complex. Hence, exogenous cannabinoid treatment may result in enhanced excitability and activity of these cells, which may lead to augmented dopamine release in NAC. Taken together with the strikingly high density of $\mathrm{CB} 1$ receptors found in the basolateral complex, this brain region-along with the hippocampus and the prefrontal cortex-is a likely candidate to convey the indirect effects of cannabinoids on dopamine release in the nucleus accumbens, thereby contributing to reward processes.

The other well known, amygdala-related behavioral effect of cannabinoids is the modulation of anxiety responses (Onaivi et al., 1990; Navarro et al., 1993; Rodriguez de Fonseca et al., 1996, 1997). Acute CB1 receptor antagonist treatment causes enhanced anxiety responses either alone or after long-term exposure to cannabinoids (Navarro et al., 1997; Rodriguez de Fonseca et al., 1997), which reduces corticotropin-releasing hormone (CRH) 
level in the central nucleus of amygdala (Rodriguez de Fonseca et al., 1997). The central nucleus is the major output region of the amygdala to the autonomic and endocrine centers of the brain (Pitkänen, 2000) and mediates stress and fear responses to aversive sensory stimuli, which often correlates with elevated $\mathrm{CRH}$ level (Davis, 2000). Therefore, the lack of CB1 receptors in the central nucleus, in contrast with the high density in the basolateral complex may seem to be surprising. However, the aversive or appetitive nature of a sensory stimulus is processed in part by the basolateral complex, and afferent inputs from these nuclei to the central nucleus constitute an important pathway in the induction of different kinds of emotional responses (Everitt et al., 2000). Interestingly, recent anatomical and physiological findings have revealed that GABAergic neurons of the so-called intercalated nuclei may serve as an important intermediate station in this pathway by generating feedforward inhibition in the central nucleus after activation of the basolateral amygdala (Paré and Smith, 1993; Royer et al., 1999). Thus, by reducing the inhibitory tone on basolateral amygdala pyramidal cells, cannabinoids may indirectly enhance the activity of GABAergic cell population in the intercalated nuclei and thereby inhibit neuronal activity in the central nucleus.

Increased activity of basolateral amygdala projection cells effectively regulates their target elements in the central nucleus and in the nucleus accumbens. Enhanced release of dopamine in the nucleus accumbens resulting in rewarding effects or decreased release of $\mathrm{CRH}$ in the central nucleus reducing anxiety responses may well be the indirect consequences of removing the tonic inhibitory control of pyramidal cell activity in the basolateral amygdala. Thus, we suggest that the inhibition of GABA release from axon terminals of local-circuit GABAergic interneurons in the basolateral amygdala by presynaptic CB1 receptors may constitute an important aspect of the neurobiological substrates of cannabinoid-induced emotional responses.

\section{REFERENCES}

Abood ME, Martin BR (1992) Neurobiology of marijuana abuse. Trends Pharmacol Sci 13:201-206.

Acsády L, Katona I, Martinez-Guijarro FJ, Buzsáki G, Freund TF (2000) Unusual target selectivity of perisomatic inhibitory cells in the hilar region of the rat hippocampus. J Neurosci 20:6907-6919.

Cador M, Robbins TW, Everitt BJ (1989) Involvement of the amygdala in stimulus-reward associations: interaction with the ventral striatum. Neuroscience 30:77-86.

Chan PK, Chan SC, Yung WH (1998) Presynaptic inhibition of GABAergic inputs to rat substantia nigra pars reticulata neurones by a cannabinoid agonist. NeuroReport 9:671-675.

Chen JP, Paredes W, Li J, Smith D, Lowinson J, Gardner EL (1990) Delta 9-tetrahydrocannabinol produces naloxone-blockable enhancement of presynaptic basal dopamine efflux in nucleus accumbens of conscious, freely-moving rats as measured by intracerebral microdialysis. Psychopharmacology (Berl) 102:156-162.

Collins DR, Paré D (1999) Reciprocal changes in the firing probability of lateral and central medial amygdala neurons. J Neurosci 19:836-844.

Davis M (2000) The role of amygdala in conditioned and unconditioned fear and anxiety. In: The amygdala. A functional analysis (Aggleton JP, ed), pp 213-288. Oxford: Oxford UP.

Egertova M, Elphick MR (2000) Localisation of cannabinoid receptors in the rat brain using antibodies to the intracellular C-terminal tail of CB. J Comp Neurol 422:159-171.

Everitt BJ, Morris KA, O'Brien A, Robbins TW (1991) The basolateral amygdala-ventral striatal system and conditioned place preference: further evidence of limbic-striatal interactions underlying rewardrelated processes. Neuroscience 42:1-18.

Everitt BJ, Cardinal RN, Hall J, Parkinson JA, Robbins TV (2000) Differential involvement of amygdala subsystems in appetitive conditioning and drug addiction. In: The amygdala. A functional analysis (Aggleton JP, ed), pp 353-390. Oxford: Oxford UP

Floresco SB, Yang CR, Phillips AG, Blaha CD (1998) Basolateral amygdala stimulation evokes glutamate receptor-dependent dopamine efflux in the nucleus accumbens of the anaesthetized rat. Eur $\mathbf{J}$ Neurosci 10:1241-1251.
French ED, Dillon K, Wu X (1997) Cannabinoids excite dopamine neurons in the ventral tegmentum and substantia nigra. NeuroReport $8: 649-652$.

Gardner EL, Vorel SR (1998) Cannabinoid transmission and rewardrelated events. Neurobiol Dis 5:502-533.

Hájos N, Katona I, Naiem SS, Mackie K, Ledent C, Mody I, Freund TF (2000) Cannabinoids inhibit hippocampal GABAergic transmission and network oscillations Eur J Neurosci 12:3239-3249.

Hájos N, Ledent C, Freund TF (2001) Novel cannabinoid-sensitive receptor mediates inhibition of glutamatergic synaptic transmission in the hippocampus. Neuroscience 106:1-4.

Hoffman AF, Lupica CR (2000) Mechanisms of cannabinoid inhibition of GABA(A) synaptic transmission in the hippocampus. J Neurosci 20:2470-2479.

Hoffman AF, Lupica CR (2001) Direct actions of cannabinoids on synaptic transmission in the nucleus accumbens: a comparison with opioids. J Neurophysiol 85:72-83.

Irving AJ, Coutts AA, Harvey J, Rae MG, Mackie K, Bewick GS, Pertwee RG (2000) Functional expression of cell surface cannabinoid $\mathrm{CB}(1)$ receptors on presynaptic inhibitory terminals in cultured rat hippocampal neurons. Neuroscience 98:253-262.

Katona I, Sperlágh B, Sik A, Köfalvi A, Vizi ES, Mackie K, Freund TF (1999) Presynaptically located CB1 cannabinoid receptors regulate GABA release from axon terminals of specific hippocampal interneurons. J Neurosci 19:4544-4558.

Katona I, Sperlágh B, Maglóczky Z, Sántha E, Köfalvi A, Czirják S, Mackie K, Vizi ES, Freund TF (2000) GABAergic interneurons are the targets of cannabinoid actions in the human hippocampus. Neuroscience 100:797-804.

Kemppainen S, Pitkänen A (2000) Distribution of parvalbumin, calretinin, and calbindin- $\mathrm{D}(28 \mathrm{k})$ immunoreactivity in the rat amygdaloid complex and colocalization with gamma-aminobutyric acid. J Comp Neurol 426:441-467.

Kreitzer AC, Regehr WG (2001) Retrograde inhibition of presynaptic calcium influx by endogenous cannabinoids at excitatory synapses onto Purkinje cells. Neuron 29:717-727.

Ledent C, Valverde O, Cossu G, Petitet F, Aubert JF, Beslot F, Böhme GA, Imperato A, Pedrazzini T, Roques BP, Vassart G, Fratta W, Parmentier M (1999) Unresponsiveness to cannabinoids and reduced addictive effects of opiates in CB1 receptor knockout mice. Science 283:401-404

LeDoux J (2000) The amygdala and emotion: a view through fear. In: The amygdala. A functional analysis (Aggleton JP, ed), pp 289-310. Oxford: Oxford UP

Louilot A, Besson C (2000) Specificity of amygdalostriatal interactions in the involvement of mesencephalic dopaminergic neurons in affective perception. Neuroscience 96:73-82.

Mailleux P, Vanderhaeghen JJ (1992) Distribution of neuronal cannabinoid receptor in the adult rat brain: a comparative receptor binding radioautography and in situ hybridization histochemistry. Neuroscience 48:655-668.

Marsicano G, Lutz B (1999) Expression of the cannabinoid receptor CB1 in distinct neuronal subpopulations in the adult mouse forebrain. Eur J Neurosci 11:4213-4225.

Martellotta MC, Cossu G, Fattore L, Gessa GL, Fratta W (1998) Selfadministration of the cannabinoid receptor agonist W IN 55,212-2 in drug-naive mice. Neuroscience 85:327-330.

Matsuda LA, Bonner TI, Lolait SJ (1993) Localization of cannabinoid receptor mRNA in rat brain. J Comp Neurol 327:535-550.

McDonald AJ (1982a) Cytoarchitecture of the central amygdaloid nucleus of the rat. J Comp Neurol 208:401-418.

McDonald AJ (1982b) Neurons of the lateral and basolateral amygdaloid nuclei: a Golgi study in the rat. J Comp Neurol 212:293-312.

McDonald AJ (1985) Morphology of peptide-containing neurons in the rat basolateral amygdaloid nucleus. Brain Res 338:186-191.

McDonald AJ, Pearson JC (1989) Coexistence of GABA and peptide immunoreactivity in non-pyramidal neurons of the basolateral amygdala. Neurosci Lett 100:53-58.

Muramoto K, Ono T, Nishijo H, Fukuda M (1993) Rat amygdaloid neuron responses during auditory discrimination. Neuroscience $52: 621-636$.

Navarro M, Fernandez-Ruiz JJ, de Miguel R, Hernandez ML, Cebeira M, Ramos JA (1993) An acute dose of delta 9-tetrahydrocannabinol affects behavioral and neurochemical indices of mesolimbic dopaminergic activity. Behav Brain Res 57:37-46.

Navarro M, Hernandez E, Munoz RM, del Arco I, Villanua MA, Carrera MR, Rodriguez de Fonseca F (1997) Acute administration of the CB1 cannabinoid receptor antagonist SR 141716A induces anxiety-like responses in the rat. NeuroReport 8:491-496.

Ohno-Shosaku T, Maejima T, Kano M (2001) Endogenous cannabinoids mediate retrograde signals from depolarized postsynaptic neurons to presynaptic terminals. Neuron 29:729-738.

Onaivi ES, Green MR, Martin BR (1990) Pharmacological characterization of cannabinoids in the elevated plus maze. J Pharmacol Exp Ther 253:1002-1009. 
Paré D, Gaudreau H (1996) Projection cells and interneurons of the lateral and basolateral amygdala: distinct firing patterns and differential relation to theta and delta rhythms in conscious cats. J Neurosci 16:3334-3350.

Paré D, Smith Y (1993) The intercalated cell masses project to the central and medial nuclei of the amygdala in cats. Neuroscience 57:1077-1090.

Pitkänen A (2000) Connectivity of the rat amygdaloid complex. In: The amygdala. A functional analysis (Aggleton JP, ed), pp 31-116. Oxford: Oxford UP.

Rainnie DG, Asprodini EK, Shinnick-Gallagher P (1991) Inhibitory transmission in the basolateral amygdala. J Neurophysiol 66:999-1009.

Rodriguez de Fonseca F, Rubio P, Menzaghi F, Merlo-Pich E, Rivier J, Koob GF, Navarro M (1996) Corticotropin-releasing factor (CRF) antagonist [D-Phe12,Nle21,38,C alpha MeLeu37]CRF attenuates the acute actions of the highly potent cannabinoid receptor agonist HU-210 on defensive-withdrawal behavior in rats. J Pharmacol Exp Ther 276:56-64.

Rodriguez de Fonseca F, Carrera MR, Navarro M, Koob GF, Weiss F (1997) Activation of corticotropin-releasing factor in the limbic system during cannabinoid withdrawal. Science 276:2050-2054.

Royer S, Martina M, Paré D (1999) An inhibitory interface gates impulse traffic between the input and output stations of the amygdala. J Neurosci 19:10575-10583.

Szabó B, Dorner L, Pfreundtner C, Norenberg W, Starke K (1998) Inhibition of GABAergic inhibitory postsynaptic currents by cannabinoids in rat corpus striatum. Neuroscience 85:395-403.

Szabó B, Muller T, Koch H (1999) Effects of cannabinoids on dopamine release in the corpus striatum and the nucleus accumbens in vitro. J Neurochem 73:1084-1089.

Takahashi KA, Linden DJ (2000) Cannabinoid receptor modulation of synapses received by cerebellar Purkinje cells. J Neurophysiol 83:1167-1180.
Takagi M, Yamamoto C (1981) The long-lasting inhibition recorded in vitro from the lateral nucleus of the amygdala. Brain Res 206:474-478

Tanda G, Pontieri FE, Di Chiara G (1997) Cannabinoid and heroin activation of mesolimbic dopamine transmission by a common mul opioid receptor mechanism. Science 276:2048-2050.

Tanda G, Munzar P, Goldberg SR (2000) Self-administration behavior is maintained by the psychoactive ingredient of marijuana in squirrel monkeys. Nat Neurosci 3:1073-1074.

Tsou K, Patrick SL, Walker JM (1995) Physical withdrawal in rats tolerant to delta 9-tetrahydrocannabinol precipitated by a cannabinoid receptor antagonist. Eur J Pharmacol 280:R13-5.

Tsou K, Brown S, Sanudo-Pena MC, Mackie K, Walker JM (1998) Immunohistochemical distribution of cannabinoid CB1 receptors in the rat central nervous system. Neuroscience 83:393-411.

Tsou K, Mackie K, Sanudo-Pena MC, Walker JM (1999) Cannabinoid CB1 receptors are localized primarily on cholecystokinin-containing GABAergic interneurons in the rat hippocampal formation. Neuroscience 93:969-975.

Vaughan CW, McGregor IS, Christie MJ (1999) Cannabinoid receptor activation inhibits GABAergic neurotransmission in rostral ventromedial medulla neurons in vitro. Br J Pharmacol 127:935-940.

Vaughan CW, Connor M, Bagley EE, Christie MJ (2000) Actions of cannabinoids on membrane properties and synaptic transmission in rat periaqueductal gray neurons in vitro. Mol Pharmacol 57:288-295.

Wilson RI, Nicoll RA (2001) Endogenous cannabinoids mediate retrograde signalling at hippocampal synapses. Nature 410:588-592.

Wilson RI, Kunos G, Nicoll RA (2001) Presynaptic specificity of endocannabinoid signaling in the hippocampus. Neuron 31:453-462.

Zimmer A, Zimmer AM, Hohmann AG, Herkenham M, Bonner TI (1999) Increased mortality, hypoactivity, and hypoalgesia in cannabinoid CB1 receptor knockout mice. Proc Natl Acad Sci USA 96:57805785 . 